\title{
PENGARUH FREE CASH FLOW, SALES GROWTH, KEBIJAKAN DIVIDEN PADA KEBIJAKAN HUTANG PERUSAHAAN PROPERTY YANG ADA DI BURSA INDONESIA
}

\author{
Adi Supriadi \\ Universitas Pamulang \\ supriadiadi83consobiz@gmail.com
}

\begin{abstract}
Abstrak
Penelitian ini bertujuan untuk mengetahui pengaruh free cash flow, sales growth dan kebijakan dividen terhadap kebijakan hutang pada perusahaan property, real estate dan kontruksi bangunan yang terdaftar di Bursa Efek Indonesia periode tahun 2014-2018. Teknik pengambilan sampel menggunakan purposive sampling, diperoleh sebanyak 20 perusahaan sampel dari populasi 53 perusahaan dengan total observasi 100 unit analisis. Teknik pengumpulan data menggunakan teknik dokumentasi yang diperoleh dari annual report dan laporan keuangan perusahaan, sedangkan teknik analisis yang digunakan adalah analisis regresi linier berganda. Free cash flow memiliki nilai thitung sebesar 3,212 dimana nilai 3,212 > 1,98472, Sales growth memiliki nilai thitung sebesar -2,631 dimana nilai $-2,631<1,98472$ dan nilai signifikan sebesar 0,010 dimana 0,010<0,05. Sehingga sales growth berpengaruh negatif signifikan terhadap kebijakan hutang, Kebijakan dividen memiliki nilai thitung sebesar 4,113 dimana nilai 4,113 > 1,98472 dan nilai signifikan sebesar 0,000 dimana nilai $0,000<0,05$. Sehingga kebijakan dividen berpengaruh positif dan signifikan terhadap kebijakan hutang. Berdasarkan hasil penelitian menunjukkan bahwa free cash flow, sales growth dan kebijakan dividen memiliki pengaruh terhadap kebijakan hutang. Penelitian ini juga dapat di jelaskan dengan melihat bahwa nilai $\mathrm{R}^{2}$ sebesar 0,251 yang berarti $25,1 \%$ variasi dari semua variabel bebas dapat menjelaskan variabel terikat dan sisanya 74,9\% diterangkan oleh variabel lain yang tidak diajukan dalam penelitian ini. Saran untuk penelitian selanjutnya diharapkan untuk menambah variabel-variabel serta proksi lain dalam model penelitian sehingga mampu memberikan gambaran variasi lain lagi dalam kebijakan hutang.

Kata kunci: Free Cash Flow, Sales Growth, Kebijakan Dividen, Kebijakan Hutang.
\end{abstract}

Abstract

This study aims to examine the effect of free cash flow, sales growth and dividend policy on debt policies in property, real estate and building construction companies listed on the Indonesia Stock Exchange for the period of 2014-2018. The sampling technique used was purposive sampling in which there were as many as 20 sample companies from a population of 53 companies with a total observation of 100 units of analysis. Data collection techniques used documentation techniques obtained from annual reports and company financial reports, whilst the analysis technique used was multiple linear regression analysis. Free cash flow has count value of 3,212 where the value is 3,212>1,98472, Sales growth has a tcount value of -2,631 where the value is -2,631 < 1,98472 and a significant value of 0.010 where $0.010<0.05$. So that sales growth has a significant negative effect on debt policy, dividend policy has a tcount value of 4.113 where the value is $4.113>1.98472$ and a significant value is 0.000 where the value is $0.000<0.05$. So that dividend policy has a positive and significant effect on debt policy.

The results of this research found that free cash flow, sales growth and dividend policy had an effect on debt policy. This research can also be explained by seeing that the $R^{2}$ value of 0.251 which means that $25.1 \%$ of the variation of all variables can explain the variable and the remaining $74.9 \%$ is explained by other variables not proposed in this study. Suggestions for further research are expected to add other variables and proxies in the research model so as to be able to provide an overview of other variations in debt policy.

\section{Pendahuluan}


Persaingan dunia bisnis menuntut perusahaan untuk menjadi lebih kreatif lagi dalam mengembangkan semua produknya dan mencari sumber pendanaan yang paling efektif. Kinerja perusahaan sangat berpengaruh pada struktur modal atau keputusan pendanaan. Kinerja perusahaan mempengaruhi keputusan apakah dana yang diperoleh berasal dari hutang atau dari penjualan saham. Dengan demikian perusahaan perlu mengusahakan suatu keseimbangan yang optimal dalam menggunakan kedua sumber tersebut sehingga dapat memaksimalkan nilai perusahaan (Dewi Nur Khusniyah, Maslichah, 2018)

Salah satu tujuan utama dari perusahaan adalah untuk meningkatkan nilai perusahaan dengan cara meningkatkan kemakmuran dari para pemilik atau pemegang saham. Peningkatan nilai perusahaan dapat dilakukan dengan cara pengaturan kegiatan manajemen yang salah satunya melalui manajemen keuangan. Kegiatan dalam pengelolaan keuangan pada dasarnya dapat dibagi menjadi dua kegiatan utama, yaitu kegiatan dalam mencari sumber dana dan kegiatan penggunaan dana (Sheisarvian, 2015).

Sumber pendanaan dapat diperoleh dari internal dan juga eksternal. Sumber dana internal berasal dari kegiatan operasional perusahaan, sedangkan sumber dana eksternal diperoleh dari dua kategori yaitu hutang dari kreditur atau penerbitan saham. Manajer perusahaan harus memilih kombinasi sumber dana perusahaan dengan teliti karena setiap sumber dana memiliki konsekuensi finansial yang berbeda-beda, termasuk hutang yang lebih berisiko mengancam likuiditas perusahaan. Perusahaan akan memilih sumber pendanaan hutang sebagai alternatif terakhir dari pendanaan sehingga kebijakan hutang harus dikelola dengan tepat untuk menjadi sumber dana yang memberikan dampak positif bagi kegiatan operasional perusahaan. Kebijakan hutang merupakan rangka memperoleh sumber pembiayaan sehingga dapat digunakan untuk membiayai aktivitas operasional. Kebijakan hutang juga berfungsi sebagai mekanisme monitoring terhadap tindakan manajer yang dilakukan dalam pengelolaan perusahaan (Bahri, 2017).

Pendanaan perusahaan dengan menggunakan hutang memiliki beberapa manfaat yaitu bunga yang timbul atas pinjaman dapat menjadi pengurangan pajak atas laba serta perusahaan juga tidak harus berbagi keuntungan kepada pemberi pinjaman (Oktariyani \& Hasanah, 2019).

Kebijakan hutang merupakan kebijakan dana dalam perusahaan yang dipergunakan untuk mendanai kegiatan operasional perusahaan. Kebijakan hutang tersebut akan menentukan kemampuan perusahaan dalam menjalankan bisnis yang dilakukan (Dewi et al., 2018). Kebijakan hutang dinilai sebagai suatu solusi dari masalah keagenan yang disebabkan oleh terdapatnya free cash flow yang dihasilkan perusahaan (Oktariyani \& Hasanah, 2019).

Free cash flow dapat menimbulkan konflik kepentingan antara pemegang saham dengan pihak manajemen. Investasi yang dilakukan oleh manajemen dengan menggunakan free cash flow tidak akan menjadi masalah jika investasi yang dilakukan tersebut berhasil, namun yang menjadi masalah apabila investasi tersebut gagal. Untuk mengatasi dugaan pemborosan free cash flow oleh pihak manajemen maka dapat dilakukan dengan pembentukan hutang. Pembentukan hutang bisa mengurangi keinginan manajemen menggunakan free cash flow untuk membiayai keinginan-keinginan yang tidak optimal dan tidak mendatangkan keuntungan (Lehn \& Poulsen, 1989).

Hutang akan mengurangi tingkat free cash flow karena perusahaan harus membayar bunga atas hutang tersebut secara periodik. Tetapi disisi lain, para pemegang saham menginginkan free cash flow dapat dibagikan kepada pemegang saham sebagai dividen (Martha et al., 2018).

Pertumbuhan penjualan (Sales growth) merupakan keberhasilan investasi pada periode sebelumnya yang dapat memprediksikan investasi diperiode berikutnya dengan melihat peluang pasar (Umi Mardiyati, Gatot Nazir Ahmad, 2012).

Sesuai dengan teori pecking order, perusahaan akan memilih pendanaan internal terlebih dahulu kemudian utang dan saham sebagai pilihan terkahir. Jadi, semakin tinggi pertumbuhan penjualan perusahaan, maka semakin tinggi pula penerimaan perusahaan. Dalam penggunaan dana eksternal perusahaan memiliki pilihan untuk menerbitkan surat hutang atau mengeluarkan saham baru (Harjito, 2011). Perusahaan cenderung lebih mempertimbangkan untuk menerbitkan surat hutang daripada mengeluarkan saham baru karena biaya emisi saham baru lebih besar daripada biaya hutang itu sendiri, sehingga dapat dikatakan bahwa dengan tingkat pertumbuhan penjualan yang tinggi perusahaan cenderung lebih banyak 
menggunakan hutang (Deviani \& Sudjarni, 2018). Kebijakan dividen dalam suatu perusahaan merupakan hal yang kompleks karena melibatkan kepentingan banyak pihak, Pembagian dividen dapat memberikan sinyal kepada para pemegang saham bahwa dana yang ditanamkan diperusahaan terus berkembang (Neswari \& Priyadi, 2017). Jika perusahaan meningkatkan pembayaran dividennya maka dana yang tersedia untuk pendanaan (laba ditahan) akan semakin kecil, sehingga untuk memenuhi kebutuhan dana perusahaan manajer cenderung menggunakan hutang lebih banyak (Masdupi, 2005).

\section{Kajian Literatur}

Teori keagenan menguraikan tentang adanya hubungan keagenan antara manajamen (agen) dengan investor juga merupakan sebuah kontrak antara agen dengan principal (Jensen \& Meckling, 1976). Hubungan yang berlangsung pada saat satu atau lebih orang, yaitu manajemen yang membutuhkan seseorang atau organisasi lain (investor) untuk melimpahkan wewenang dalam melakukan keputusan kepada manajemen tersebut (Nofiani \& Gunawan, 2018). Konflik kepentingan ini terus meningkat karena pihak principal tidak dapat memonitor aktivitas agent sehari-hari untuk memastikan bahwa agent bekerja sesuai dengan keinginan para pemegang saham (Simanungkalit, 2017).

Pecking order theory merupakan teori yang menjelaskan mengapa perusahaan akan menentukan hierarki sumber dana yang paling disukai (Myers, 1984), teori ini mendasarkan diri atas informasi asimetrik (asymmetric information), suatu istilah yang menunjukkan bahwa manajemen mempunyai informasi yang lebih banyak (tentang prospek, risiko dan nilai perusahaan) daripada pemodal publik (Safitri \& Akhmadi, 2017).

Kebijakan hutang merupakan tindakan manajemen perusahaan dalam rangka mendanai operasional perusahaan dengan menggunakan modal yang berasal dari hutang (Oktariyani \& Hasanah, 2019). Jangka waktu utang dibedakan menjadi dua, yaitu: utang jangka pendek dan utang jangka panjang (Ahmad \& Munawir, 2018). Faktor yang memiliki pengaruh terhadap kebijakan hutang, diantaranya Non Debt Tax Shield (NDT), Struktur Aktiv, Profitabilitas, Risiko Bisnis, Struktur Kepemilikan Institusional, Kondisi Internal Perusahaan (Mega Mulianti, 2010).

Free Cash Flow merupakan arus kas yang benar-benar tersedia untuk dibayarkan kepada investor (pemegang saham dan pemilik utang) setelah perusahaan melakukan investasi dalam asset tetap, produk baru, dan modal kerja yang dibutuhkan untuk mempertahankan operasi yang sedang berjalan (Brigham et al., 2011). Free cash flow dapat menimbulkan konflik kepentingan antara manajer dengan pemegang saham yang disebut dengan konflik keagenan (Palestin, 2008). Manajer akan memilih dana tersebut dapat di investasikan lagi kepada proyek-proyek yang dapat menghasilkan keuangan karena mampu meningkatkan insentif yang diterimanya (Jensen, 1986).

Pihak manajemen yang perlu mempertimbangkan sumber pendanaan yang tepat bagi pembelanjaan asset (Umi Mardiyati, Gatot Nazir Ahmad, 2012). Pertumbuhan penjualan juga merupakan suatu indicator permintaan dan daya saing perusahaan dalam suatu industri (Brigham et al., 2011). Sesuai dengan penjelasan diatas hubungan pecking order theory dengan sales growth yaitu perusahaan akan memilih pendanaan internal terlebih dahulu kemudian hutang dan saham sebagai pilihan terakhir.

Kebijakan dividen merupakan bagian yang tidak dapat dipisahkan dengan keputusan pendanaan perusahaan (Bahri, 2017). Kebijakan dividen yang optimal yaitu ketika kebijakan tersebut dapat menciptakan keseimbangan antara dividen saat ini dengan pertumbuhan di masa yang akan datang sehingga bisa untuk memaksimumkan harga saham (Sudirman, 2015). Berbagai pendapat tentang dividen bisa dikelompokkan menjadi tiga, pertama menginginkan deviden di bagikan sebesar-besarnya, kedua kebijakan deviden tidak relevan, ketiga perusahaan membagikan deviden sekecil mungkin (Husnan \& Pudjiastuti, 1994). 
Berdasarkan penjelasan diatas dapat digambarkan model penelitian sebagai berikut:

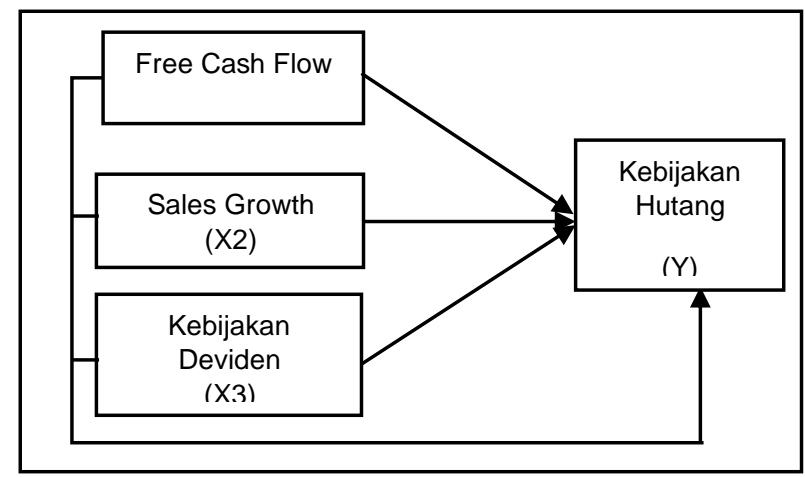

Free cash flow sering menjadi pemicu timbulnya konflik kepentingan antara manajemen dengan pemegang saham. Manajemen biasanya lebih suka untuk menginvestasikan lagi dana tersebut pada proyek-proyek yang dapat menghasilkan keuntungan. Disisi lain, pemegang saham mengharapkan dana tersebut dibagikan sehingga akan meningkatkan kemakmuran bagi para pemegang saham. Free cash flow memiliki pengaruh terhadap kebijakan hutang (Posner \& Jensen, 2009). Berdasarkan uraian diatas maka dapat dirumuskan hipotesis pertama sebagai berikut:

H1: Diduga free cash flow berpengaruh terhadap kebijakan hutang.

Dari sudut pandang investor, pertumbuhan suatu perusahaan merupakan tanda perusahaan memiliki aspek yang menguntungkan, dan investor pun akan mengaharapkan tingkat pengembalian (rate of return) dari investasi yang dilakukan bahwa menunjukkan perkembangan yang baik. Tahap pertumbuhan suatu perusahaan dapat berpengaruh pada kemampuan untuk mempertahankan keuntungan dalam mendanai kesempatan - kesempatan dimasa yang akan mendatang (Suweta \& Dewi, 2016). Sales growth memiliki pengaruh terhadap kebijakan hutang (Zuhria \& Riharjo, 2016). Berdasarkan uraian diatas maka dapat dirumuskan hipotesis kedua sebagai berikut:

H2: Diduga sales growth berpengaruh terhadap kebijakan hutang.

Perusahaan cenderung membayarkan dividen yang lebih besar apabila proporsi saham yang dimiliki manajemen lebih rendah. kebijakan dividen memiliki pengaruh terhadap kebijakan hutang (Sheisarvian, 2015). Berdasarkan uraian diatas maka dapat dirumuskan hipotesis ketiga sebagai berikut:

H3: Diduga kebijakan dividen berpengaruh terhadap kebijakan hutang.

Kebijakan hutang akan mendorong pihak manajer untuk lebih berhati-hati dalam mengoptimalkan penggunaan dana tersebut karena dengan hutang maka perusahaan memiliki kewajiban untuk melakukan pembayaran atas bunga dan pinjaman pokoknya secara periodik. Free cash flow sering menjadi pemicu timbulnya perbedaan kepentingan antara pemegang saham dengan manajer. Kebijakan dividen merupakan bagian yang tidak dapat dipisahkan dengan keputusan pendanaan perusahaan. Kas lebih perusahaan yang dapat didistribusikan kepada pemegang saham atau kreditor yang tidak diperlukan untuk modal kerja atau investasi pada asset tetap (Zuhria \& Riharjo, 2016). Kebijakan hutang merupakan kebijakan pendanaan perusahaan dengan menggunakan modal yang berasal dari hutang yang dilakukan oleh pihak manajemen untuk membiayai aktivitas operasional perusahaan (Oktariyani \& Hasanah, 2019). Pertumbuhan penjualan merupakan keberhasilan investasi pada periode sebelumnya yang dapat memprediksikan investasi di periode berikutnya dengan melihat peluang pasar (Suweta \& Dewi, 2016). Berdasarkan uraian diatas maka dapat dirumuskan hipotesis keempat sebagai berikut:

H4: Diduga free cash flow, sales growth dan kebijakan dividen secara bersama-sama berpengaruh terhadap kebijakan hutang.

\section{Metode Penelitian}


Metode yang digunakan dalam penelitian ini adalah metode penelitian yang bersifat kuantitatif. Metode kuantitatif dapat diartikan sebagai metode penelitian yang berlandaskan pada filsafat positivisme, yang digunakan untuk meneliti pada populasi atau sampel tertentu, pengumpulan data menggunakan instrumen penelitian, analisis data bersifat kuantitatif atau statistik (Sugiyono, 2015). Objek penelitian dalam penelitian ini yaitu perusahaan property, real estate dan kontruksi bangunan yang terdaftar di Bursa Efek Indonesia selama periode tahun 2014 - 2018.

Pengukuran operasional merupakan penjelasan teoritis variabel sehingga dapat diamati dan diukur dalam menganalisa data yang telah dikumpulkan oleh penulis. Kebijakan hutang merupakan kebijakan yang diambil oleh pihak manajemen dalam rangka memperoleh sumber pembiayaan (dana) dari pihak ketiga untuk membiayai operasional perusahaan (Akbar \& Ruzikna, 2016). Kebijakan hutang dapat diproksikan dengan debt to equity ratio (DER) yaitu perbandingan antara total hutang yang didapat dari penjumlahan antara utang jangka panjang dan utang jangka pendek dalam satu periode dengan total modal yang didapat dari penjumlahan modal sendiri dan modal yang ada. Semakin tinggi DER maka diasumsikan memiliki risiko yang tinggi terhadap likuiditas perusahaan (Mardiyati \& dkk, 2014). Dengan rumus sebagai berikut:

$$
\text { DER }=\frac{\text { Total Debt }}{\text { Total Equity }} \times 100
$$

Variabel independen atau variabel bebas merupakan variabel yang mempengaruhi atau yang menjadi sebab perubahannya atau timbulnya variabel dependen (terikat). Dalam SEM (Structural Equation Modeling/ Permodelan Persamaan Struktural), variabel independen disebut sebagai variabel eksogen (Sugiyono, 2018).

Free cash flow dapat digunakan untuk membayar hutang, pembelian kembali saham, pembayaran, dividen atau disimpan untuk kesempatan pertumbuhan perusahaan masa mendatang (Oktariyani \& Hasanah, 2019). Free cash flow dalam penelitian ini diukur dengan rasio free cash flow to total asset yaitu free cash flow dibagi total asset (Posner \& Jensen, 2009), maka proksi free cash flow dalam penelitian ini menggunakan rumus sebagai berikut:

$$
\text { FCF }=\frac{\text { AKOit }- \text { PMit }- \text { NWCit }}{\text { Total Asset }}
$$

Perusahaan yang memiliki penjualan yang stabil dapat lebih aman dalam mendapatkan banyak pinjaman dan menanggung biaya tetap yang lebih tinggi dibandingkan dengan perusahaan dengan penjualan yang tidak stabil (Brigham et al., 2011). Sales growth diukur dengan perbandingan antara selisih penjualan tahun berjalan dikurangi penjualan tahun sebelumnya terhadap penjualan tahun sebelumnya (Umi Mardiyati, Gatot Nazir Ahmad, 2012). Sales growth dapat dihitung dengan rumus sebagai berikut:

$\begin{gathered}\text { Sales } \\ \text { Growth }\end{gathered}=\frac{{\text { Penj. } \text { tahun }_{\mathrm{t}}-\text { Penj. Thn }_{\mathrm{t}-1}}_{\text {Penj. Thn }}^{\mathrm{t}-1}}{\text { P. }}$

Kebijakan dividen merupakan kebijakanı perusanaalı yalıg veIkallaıl uengan tiga hal yaitu penentuan berapa besar laba bersih yang akan dibagikan dalam bentuk dividen, dalam bentuk apa dividen itu akan dibagikan, dan pertumbuhan dividen yang bagaimanakah yang sebaiknya digunakan oleh perusahaan (Sheisarvian, 2015). Kebijakan dividen dalam perusahaan dapat diukur dengan membandingkan antara dividen degan laba bersih setelah pajak (dividend payout ratio) (Bahri, 2017). Kebijakan dividen dapat dihitung dengan rumus sebagai berikut:

$$
\text { DPR }=\frac{\text { Dividen }}{\text { LabaBersihSetelahPajak }}
$$


Populasi merupakan wilayah generalisasi yang terdiri atas obyek atau subyek yang mempunyai kuantitas dan karakteristik tertentu yang ditetapkan oleh peneliti untuk dipelajari dan kemudian ditarik kesimpulannya (Sugiyono, 2018).

Populasi dalam penelitian ini adalah perusahaan property, real estate dan kontruksi bangunan yang terdaftar di Bursa Efek Indonesia tahun 2014 - 2018 terdapat 53 perusahaan. Teknik pengambilan sampel penelitian ini menggunakan metode purposive sampling merupakan sampel yang ditentukan berdasarkan kriteria pemilihan sampel yang telah ditemukan (Sugiyono, 2018).

\section{Hasil dan Pembahasan}

Variabel dependen atau variabel terikat merupakan variabel yang dipengaruhi atau yang menjadi akibat, karena adanya variabel bebas (Sugiyono, 2018). Dalam SEM (Structural Equation Modeling/ Permodelan Persamaan Struktural), variabel dependen disebut sebagai variabel endogen. Variabel dependen dalam penelitian ini adalah kebijakan hutang (Y). kebijakan hutang merupakan kebijakan yang diambil oleh pihak manajemen dalam rangka memperoleh sumber pembiayaan (dana) dari pihak ketiga untuk membiayai operasional perusahaan (Zuhria \& Riharjo, 2016).

Tabel 1. Hasil Uji statistik deskriptif secara ringkas

\begin{tabular}{|l|l|l|l|l|l|}
\hline \multicolumn{7}{|l|}{ Des Statistics } \\
\hline & $\mathrm{N}$ & Min & Max & Mean & Std. Dev \\
\hline Free Cash Flow & 100 & -.36 & .38 & -.05 & .11 \\
\hline Sales Growth & 100 & -.36 & .90 & .10 & .22 \\
\hline Kebijakan Dividen & 100 & .02 & 1.89 & .25 & .26 \\
\hline Kebijakan Hutang & 100 & .09 & 5.26 & 1.37 & 1.06 \\
\hline Valid N (listwise) & 100 & & & & \\
\hline
\end{tabular}

Metode analisis data dalam penelitian ini menggunakan statistik deskriptif. Statistik deskriptif adalah statistik yang memberikan gambaran atau deskripsi suatu data yang dilihat dari nilai rata-rata (mean), standar deviasi, maksimum, minimum. Penjelasan tabel diatas sebagai berikut;

1. Nilai rata-rata free cash flow $-0,058583$ dengan nilai minimum $-0,3600$ adalah perusahaan Waskita Karya (Persero) Tbk pada tahun 2015 dan nilai maksimum sebesar 0,3822 adalah perusahaan Metropolitan Kentjana Tbk pada tahun 2014. Sedangkan nilai standar deviasinya 0.1109501.

2. Nilai rata-rata sales growth 0,107357 dengan nilai minimum -0,3658 adalah perusahaan Bekasi Fajar Industrial Estate pada tahun 2014 dan nilai maksimum sebesar 0,9006 adalah perusahaan Waskita Karya (Persero) Tbk pada tahun 2017. Sedangkan nilai standar deviasinya 0.2239804 .

3. Nilai rata-rata kebijakan dividen 0,253910 dengan nilai minimum 0,0264 adalah perusahaan Gowa Makassar Tourism Development Tbk pada tahun 2018 dan nilai maksimum sebesar 1.8955 adalah perusahaan Acset Indonusa Tbk tahun 2018. Sedangkan nilai standar deviasinya 0.2673007.

4. Nilai rata-rata kebijakan hutang 1.373093 dengan nilai minimum 0,0921 adalah perusahaan Roda Vivatex Tbk tahun 2018 dan nilai maksimum sebesar 5,2633 adalah perusahaan Acset Indonusa Tbk tahun 2018. Sedangkan nilai standar deviasinya 1.0662778.

\section{Uji Normalitas}

Uji normalitas data digunakan untuk mengetahui apakah data-data telah terdistribusi normal. Pada saat melakukan uji normalitas, peneliti melakukan transformasi data. Model transformasi data yang digunakan yaitu dengan cara mengubah data kedalam bentuk Log natural (Ln) pada setiap variabel, agar nilai residual terdistribusi normal dan independen. Apabila data tidak normal maka uji statistik akan tergradasi (penurunan mutu). Uji normalitas data dapat dilakukan dengan cara analisis grafik (grafik normal P-plot dan grafik histogram) dan analisis statistik Kolmogorov-smirnov. 


\section{Analisis Grafik}

Uji normalitas dapat dideteksi dengan melihat normal probability plot. Distribusi normal akan membentuk suatu garis lurus diagonal dan ploting data residual akan dibandingkan dengan garis diagonal. Jika distribusi data residual normal, maka garis yang menggambarkan data sesungguhnya akan mengikuti garis diagonalnya. Grafik tersebut dapat dilihat pada gambar berikut:

Grafik. 1

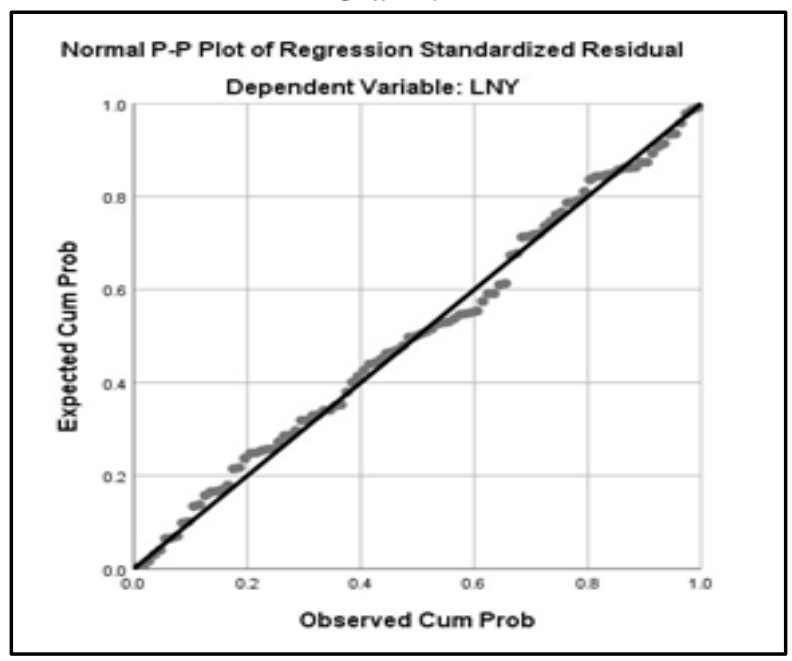

Grafik. 2

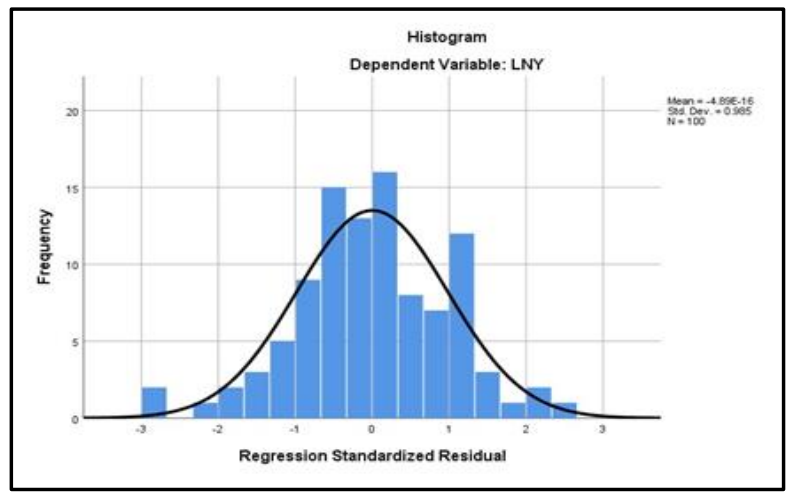

Dengan melihat gambar grafik 1 dan grafik 2 dapat disimpulkan bahwa pada grafik normal P-Plot terlihat titik-titik menyebar tidak jauh dari sekitar garis diagonalnya, serta grafik normal histogram memberikan pola normal. Sehingga grafik ini menunjukkan bahwa model regresi dapat disimpulkan data berdistribusi normal.

\section{Analisis Statistik (Kolmogorov-Smirnov)}

Dasar pengambilan keputusan pada uji statistik Kolmogorov-Smirnov (KS) ini adalah dengan melihat nilai probabilitas signifikan data residual. Jika angka probabilitas $<0.05$ maka variabel ini tidak berdistribusi secara normal. Tetapi jika angka probabilitas $>0.05$ maka variabel terdistribusi secara normal. Adapun hasil uji normalitas dengan menggunakan uji statistic Kolmogorov-Smirnov dapat dilihat berikut:

Tabel 2. Kolmogorov-Smirnov 


\begin{tabular}{|c|c|c|}
\hline & & Unstandardized Residual \\
\hline \multicolumn{2}{|l|}{$\mathrm{N}$} & 100 \\
\hline \multirow[t]{2}{*}{ Normal Parameters ${ }^{\mathrm{a}, \mathrm{b}}$} & Mean & .0000000 \\
\hline & Std. Deviation & .66270077 \\
\hline \multirow{3}{*}{ Most Extreme Differences } & Absolute & .055 \\
\hline & Positive & .055 \\
\hline & Negative & -.045 \\
\hline Test Statistic & & .055 \\
\hline Asymp. Sig. (2-tailed) & & $.200^{c, d}$ \\
\hline
\end{tabular}

a. Test distribution is Normal.

b. Calculated from data.

c. Lilliefors Significance Correction.

d. This is a lower bound of the true significance.

Berdasarkan tabel 2 hasil uji Kolmogorov-Smirnov diperoleh angka test statistic sebesar 0,055 dan nilai Asymp. Sig. (2-tailed) yaitu sebesar 0,200 jauh diatas $\alpha=0.05$ yang menunjukkan bahwa data terdistribusi secara normal.

Uji Multikulinieritas

Uji multikolinieritas bertujuan untuk menguji apakah model regresi ditemukan adanya korelasi antar variabel bebas (independen).

Model regresi yang baik seharusnya tidak terjadi korelasi antar variabel independen (Ghozali, 2018:107).Untuk mendeteksi adanya gejala multikolinieritas dalam model penelitian ini dilihati dari nilai Tolerance atau Variance Inflation Factor (VIF). Batas Tolerance $>0.10$ dan batas VIF <10. Berikut hasil uji multikolinieritas

\section{Tabel 3. Hasil Uji Multikolinieritas}

\begin{tabular}{|c|c|c|c|c|c|c|c|c|}
\hline & & \multicolumn{7}{|c|}{ Coefficients ${ }^{\mathrm{a}}$} \\
\hline & & \multicolumn{2}{|c|}{ Unstand Coef } & \multirow{2}{*}{$\begin{array}{l}\text { StandCoef } \\
\text { Beta } \\
\end{array}$} & \multirow[b]{2}{*}{$\mathrm{t}$} & \multirow[b]{2}{*}{ Sig. } & \multicolumn{2}{|c|}{ Coll Stat } \\
\hline \multicolumn{2}{|c|}{ Model } & B & Std. Error & & & & Tol & VIF \\
\hline \multirow[t]{4}{*}{1} & $\mathrm{C}$ & .33 & .50 & & .66 & .51 & & \\
\hline & LNX1 & 2.92 & .91 & .29 & 3.21 & .00 & .90 & 1.10 \\
\hline & LNX2 & -1.31 & .50 & -.23 & -2.63 & .01 & .93 & 1.07 \\
\hline & LNX3 & .342 & .08 & .36 & 4.11 & .00 & .97 & 1.02 \\
\hline
\end{tabular}

Berdasarkan data tabel 3 diatas, angka yang didapat dalam kolom tolerance menunjukkan Free Cash Flow (X1) 0,908, Sales Growth (X2) 0,930 dan Kebijakan Dividen (X3) 0,975. Secara keseluruhan variabel independen memiliki nilai > 0,10 yang artinya tidak terdapat korelasi antar variabel independen. Angka didapat dalam kolom VIF untuk Free Cash Flow (X1) 1,102, Sales Growth (X2) 1,075 dan Kebijakan Dividen (X3) 1,026 yang artinya $<10$. Maka dapat dinyatakan model ini terbebas dari mutikolinieritas antar variabel independen.

Uji Autokorelasi

Uji autokorelasi bertujuan untuk menguji apakah dalam model regresi linier terdapat korelasi antara kesalahan pengganggu pada periode $t$ dengan kesalahan pengganggu pada periode t-1 (sebelumnya). Jika terjadi koreksi, maka dinamakan ada problem autokorelasi. Model regresi yang baik adalah regresi yang 
terbebas dari autokorelasi (Sugiyono, 2018). Pada saat melakukan uji autokorelasi peneliti melakukan pengobatan agar tidak menimbulkan problem autokorelasi. Untuk mengatasi problem autokorelasi, metode yang dilakukan yaitu dengan menggunakan Durbin Watson Two Step Methode. Jika nilai DW diantara DU dan 4-DU dengan rumus DU<DW<4-DU maka dinyatakan tidak terjadi autokorelasi. Berikut hasil uji autokorelasi dalam penelitian ini:

Tabel 4. Hasil Uji Autokorelasi Durbin Watson Two Step Methode

\begin{tabular}{|l|l|l|l|l|l|}
\hline \multicolumn{7}{|c|}{ Model Summary } \\
\hline Model & $\mathrm{R}$ & R Square & Adjusted R Square & $\begin{array}{l}\text { Std. Error of the } \\
\text { Estimate }\end{array}$ & $\begin{array}{l}\text { Durbin- } \\
\text { Watson }\end{array}$ \\
\hline 1 & $.328^{\mathrm{a}}$ & .108 & .080 & .51465 & 1.759 \\
\hline
\end{tabular}

a. Predictors: (Constant), LnX3@1, LnX2@1, LnX1@1

b. Dependent Variable: LnY@1

Berdasarkan hasil dari Tabel 4.diperoleh bahwa nilai Durbin-Watson adalah 1,759 dengan taraf signifikansi $5 \%$ untuk $\mathrm{N}=$ jumlah variabel bebas sebanyak 3 dan sig $=0,05$ diperoleh DU sebesar 1,7355 dan DL 1,6108. Oleh karena itu nilai $\mathrm{dw}$ berada pada $\mathrm{DU}<\mathrm{DW}<4$-DU atau $1.7355<1,759<2,2645$ maka tidak terdapat autokorelasi sehingga model ini layak digunakan untuk analisis selanjutnya.

Uji Heteroskedastisitas

Uji heteroskedastisitas bertujuan menguji apakah dalam model terjadi kesamaan variance dari residual satu pengamatan lain (Ghozali, 2018:137). Untuk menguji adanya heteroskedastisitas dalam penelitian ini menggunakan grafik scatterplot. Berikut adalah hasil uji heteroskedastisitas dengan grafik scatterplot:

Grafik 3. Grafik scatterplot

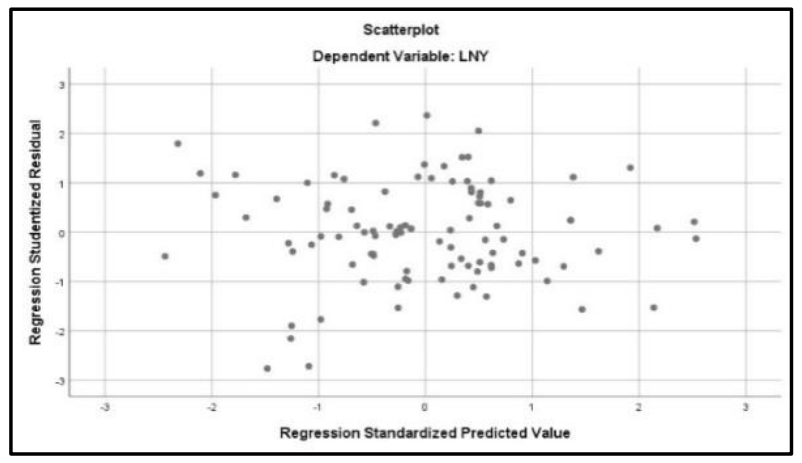

Dari grafik scatterplot diatas dapat terlihat bahwa titik-titik menyebar secara acak. Ini menunjukkan bahwa tidak terjadi heteroskedastisitas pada model regresi, sehingga model regresi layak dipakai untuk uji selanjutnya.

Untuk mendapatkan tingkat uji heteroskedastisitas yang lebih signifikan maka penelitian ini juga menggunakan uji glejser. Berikut adalah hasil uji heteroskedastisitas dengan uji glejser:

\begin{tabular}{|l|l|l|l|l|l|l|}
\hline \multicolumn{7}{|l|}{ Coefficients $^{\mathrm{a}}$} \\
\hline \multirow{2}{*}{ Model } & \multicolumn{2}{l|}{ UnstandarCoef } & \multicolumn{2}{l|}{ Standard Coef } & & \\
\cline { 2 - 5 } & $\mathrm{B}$ & Std. Error & Beta & $\mathrm{t}$ & \multirow{2}{*}{ Sig. } \\
\hline 1 & $\mathrm{C}$ & .507 & .305 & & 1.666 & .099 \\
\hline
\end{tabular}




\begin{tabular}{|l|l|l|l|l|l|}
\hline LNX1 & -.681 & .555 & -.128 & -1.228 & .223 \\
\hline LNX2 & .468 & .305 & .158 & 1.533 & .129 \\
\hline LNX3 & .009 & .051 & .018 & .177 & .860 \\
\hline
\end{tabular}

\section{Tabel 5. Hasil Uji Glejser}

Berdasarkan tabel 5 diatas diperoleh nilai signifikan variabel free cash flow sebesar 0,223, sales growth sebesar 0,129 dan kebijakan dividen sebesar 0,860. Syarat dikatakan lolos uji heteroskedastisitas yaitu nilai sig > 0.05, dari hasil tersebut menunjukkan bahwa signifikan variabel independen diatas 0.05. Sehingga dapat disimpulkan bahwa tidak terdapat gejala heteroskedastisitas.

Analasis Regresi Linier Berganda

Analisis regresi linier berganda digunakan untuk mengetahui signifikan tidaknya pengaruh variabel bebas free cash flow, sales growth dan kebijakan dividen terhadap variabel terikat yaitu kebijakan hutang. Maka hasil uji regresi linier berganda adalah sebagai berikut:

Tabel 6. Hasil Uji Regresi Linier Berganda

\begin{tabular}{|c|c|c|c|c|c|c|}
\hline & & Coeffic & & & & \\
\hline & & Unstanc & & Standar Coef & & \\
\hline & Model & B & Std. Error & Beta & t & Sig. \\
\hline 1 & C & .330 & .500 & & .661 & .510 \\
\hline & LNX1 & 2.926 & .911 & .293 & 3.212 & .002 \\
\hline & LNX2 & -1.318 & .501 & -.237 & -2.631 & .010 \\
\hline & LNX3 & .342 & .083 & .362 & 4.113 & .000 \\
\hline
\end{tabular}

Berdasarkan $\mathrm{Y}=0,330+2,926-1,318+0,342+0,500$ persamaan regresi linier berganda diatas dapat di intreprestasikan sebagai berikut:

1. Nilai konstan sebesar 0,330 dengan nilai positif, menyatakan bahwa jika free cash flow, sales growth, kebijakan dividen dianggap konstan, maka kebijakan hutang nilainya akan meningkat sebesar 0,330 .

2. Koefisien regresi pada variabel free cash flow sebesar 2,926 dengan nilai positif, hal ini menunjukkan jika variabel free cash flow bertambah satu satuan maka variabel kebijakan hutang meningkat sebesar 2,926 dengan catatan variabel lain dianggap konstanta.

3. Koefisien regresi variabel sales growth sebesar -1,318 dengan nilai negatif, maka hal ini menunjukkan jika variabel sales growth bertambah satu satuan maka variabel kebijakan hutang akan menurun sebesar $-1,318$ dengan catatan variabel lain dianggap sebagai konstanta.

4. Koefisien regresi pada variabel kebijakan dividen sebesar 0,342 dengan nilai positif, maka hal ini menunjukkan jika variabel kebijakan dividen bertambah satu satuan maka variabel kebijakan hutang meningkat sebesar 0,342 dengan catatan variabel lain dianggap konstanta.

Pengujian Hipotesis

Koefisien determinasi $\left(\mathrm{R}^{2}\right)$ digunakan untuk mengukur seberapa besar variabel independen free cash flow, sales growth dan kebijakan dividen mempengaruhi perubahan yang akan terjadi antara variabel dependen kebijakan hutang.

Tabel 7. Hasil Uji Koefisien Determinasi $\left(\mathrm{R}^{2}\right)$ 


\begin{tabular}{|l|l|l|l|l|}
\hline Model & R & R Square & Adj R Square & Std. Error of the Est \\
\hline 1 & $.523^{\mathrm{a}}$ & .274 & .251 & .67298 \\
\hline
\end{tabular}

Berdasarkan hasil tabel 7. Hasil Uji Koefisien Determinasi $\left(\mathrm{R}^{2}\right)$ diatas menunjukkan bahwa besarnya nilai koefisien determinasi (adjust $R$ Square) sebesar 0,251 dengan standar error sebesar 0.67298. Hal ini menunjukkan 25,1\% variabel kebijakan hutang dapat dijelaskan oleh variabel independen yaitu free cash flow, sales growth, dan kebijakan dividen, sisanya $(100 \%-25,1 \%=74,9 \%)$ dijelaskan oleh variabel lain yang tidak ada dalam penelitian ini seperti profitabilitas, ukuran perusahaan, kepemilikan manajerial, kepemilikan institusional dan lain-lain.

Uji statistik t pada dasarnya menunjukkan seberapa jauh pengaruh satu variabel independen secara individual dalam menerangkan variasi variabel dependen. Uji t di jelaskan dalam tabel berikut ini:

Tabel 8. Hasil Uji Statistik t

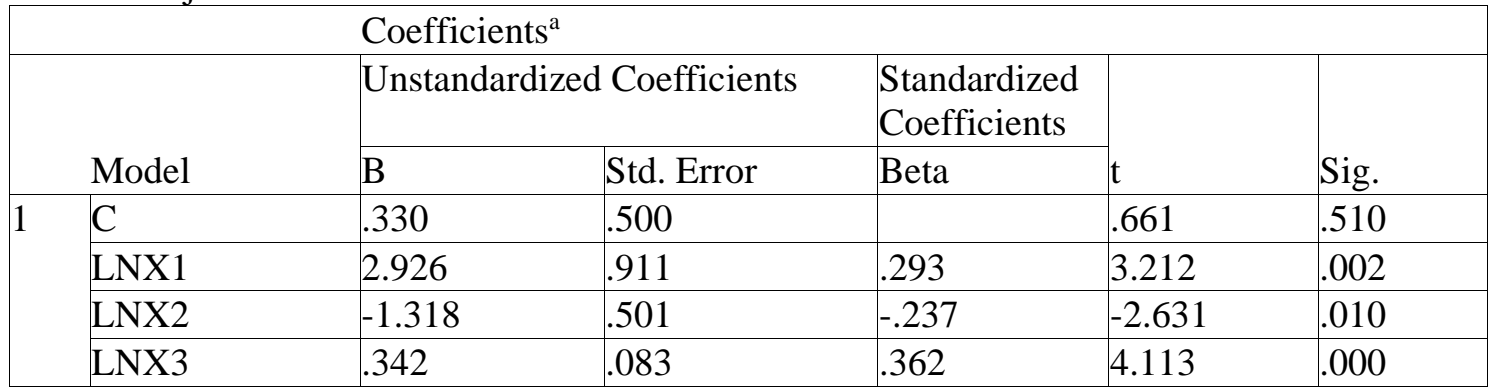

Berdasarkan pada tabel diatas maka penelitian ini diperoleh nilai sebesar 1.98472 dan taraf Signifikan a adalah sebesar 0.05. Berdasarkan uji statistik diketahui bahwa:

1. Free cash flow memiliki nilai thitung sebesar 3,212 dimana nilai 3,212>1.98472 dan nilai signifikan sebesar 0.002 dimana nilai $0,002<0.05$. Sehingga free cash flow berpengaruh positif dan signifikan terhadap kebijakan hutang.

2. Sales growth memiliki nilai thitung sebesar $-2,631$ dimana nilai $-2,631<1,98472$ dan nilai signifikan sebesar 0,010 dimana $0,010<0,05$. Sehingga sales growth berpengaruh negatif signifikan terhadap kebijakan hutang.

3. Kebijakan dividen memiliki nilai thitung sebesar 4,113 dimana nilai 4,113>1,98472 dan nilai signifikan sebesar 0,000 dimana nilai $0,000<0,05$. Sehingga kebijakan dividen berpengaruh positif dan signifikan terhadap kebijakan hutang.

Uji statistik F digunakan untuk mengetahui apakah variabel independen secara bersama-sama mempengaruhi variabel dependen. Hasil uji F dapat dilihat pada tabel 9 sebagai berikut:

Tabel 9. Hasil Uji Statistik F

\begin{tabular}{|l|l|l|l|l|l|l|}
\hline \multicolumn{8}{|c|}{ ANOVA $^{\text {a }}$} \\
\hline \multicolumn{1}{|c|}{1} & Model & Sum of Squares & df & Mean Square & F & Sig. \\
\hline & Regression & 16.398 & 3 & 5.466 & 12.069 & $.000^{\mathrm{b}}$ \\
\cline { 2 - 8 } & Residual & 43.478 & 96 & .453 & & \\
\cline { 2 - 8 } & Total & 59.876 & 99 & & & \\
\hline
\end{tabular}

Berdasarkan hasil uji statistik F, menyatakan bahwa hasil uji statistik F dapat dilihat dari tabel di atas nilai Fhitung diperoleh sebesar 12,069 dengan tingkat signifikansi sebesar 0,000. Sedangkan untuk 
mencari Ftabel dengan jumlah sampel $(n)=100$, jumlah variabel $=3$, taraf signifikan $(a)=0.05$, maka $\mathrm{df}$ pembilang $=\mathrm{k} 1=3-1=2$ dan df penyebut $=\mathrm{n}-\mathrm{k}=100-3=97$.

Menggunakan tabel distribusi $\mathrm{F}$ dan taraf signifikan 0.05 diperoleh hasil nilai Ftabel sebesar 3,09, berarti Fhitung $>$ Ftabel $(12,069>3,09)$ dengan tingkat signifikansi $0,000<0,05$.

Hal demikian menunjukkan bahwa $\mathrm{H} 4$ diterima, artinya variabel free cash flow, sales growth dan kebijakan dividen berpengaruh signifikan terhadap kebijakan hutang.

Pembahasan Hasil Penelitian, Berdasarkan hasil pengujian diatas dapat disimpulkan sebegai berikut:

1. Pengaruh Free Cash Flow terhadap Kebijakan Hutang

Variabel free cash flow terhadap kebijakan hutang secara parsial menunjukkan tingkat nilai signifikan sebesar 0,002 dimana nilai 0,002 <0,05. Sehingga penelitian ini berhasil membuktikan bahwa free cash flow mempunyai pengaruh signifikan terhadap kebijakan hutang. Hasil penelitian yang dilakukan konsisten dengan penelitian yang dilakukan oleh Andriati dan Simbolon (2016), Nofiani (2018), Zurriah dan Sembiring (2018) yang menyatakan bahwa variabel free cash flow berpengaruh positif dan signifikan terhadap kebijakan hutang. Namun terdapat pula hasil penelitian yang tidak sejalan dengan penelitian yang dilakukan, seperti penelitian yang dilakukan oleh Oktariyani dan Hasanah (2019), (Akbar \& Ruzikna, 2016), (Bahri, 2017) yang menyatakan bahwa free cash flow tidak berpengaruh terhadap kebijakan hutang. Free cash flow sering menjadi pemicu timbulnya konflik kepentingan antara manajemen dengan pemegang saham. Manajemen biasanya lebih suka untuk menginvestasikan kembali dana tersebut pada proyek-proyek yang dapat menghasilkan keuntungan. Disisi lain, pemegang saham mengharapkan dana tersebut dibagikan sehingga akan meningkatkan kemakmuran bagi para pemegang saham. Free cash flow yang semakin besar maka kesanggupan perusahaan dalam membayarkan hutangnya juga semakin besar, sehingga ketika perusahaan memiliki free cash flow yang memadai maka kebijakan hutang dapat diambil alih oleh pihak manajer perusahaan. Free cash flow yang semakin tinggi maka semakin tinggi pula kebijakan hutang perusahaan. Dengan adanya hutang dapat digunakan untuk mengendalikan penggunaan free cash flow yang berlebih oleh manajer. Manajemen akan bekerja lebih efisien agar tidak terjadi kegagalan keuangan sehingga akan mengurangi biaya agensi arus kas bebas. Sehingga H1 penelitian ini diterima yang menyatakan bahwa free cash flow secara parsial berpengaruh terhadap kebijakan hutang.

2. Pengaruh Sales Growth terhadap Kebijakan Hutang

Variabel sales growth terhadap kebijakan hutang secara parsial menunjukkan tingkat nilai signifikan sebesar 0,010 dimana $0,010<0.05$. Sehingga penelitian ini berhasil membuktikan bahwa sales growth mempunyai pengaruh yang signifikan terhadap kebijakan hutang. Hasil penelitian yang dilakukan konsisten dengan penelitian yang dilakukan oleh Zuhria dan Riharjo (2016), Mardiyati, dkk (2018), Hikmawati, dkk (2017) yang menyatakan bahwa sales growth berpengaruh terhadap kebijakan hutang. Namun terdapat pula hasil penelitian yang tidak sejalan dengan penelitian yang dilakukan, seperti penelitian yang dilakukan oleh Putri (2016) yang menyatakan bahwa sales growth tidak memiliki pengaruh terhadap kebijakan hutang. Ketika perusahaan memiliki tingkat pertumbuhan penjualan yang tinggi dan semakin meningkat maka mengisyaratkan adanya kebutuhan pendanaan yang lebih besar. Ketika kas internal di rasa tidak cukup untuk memenuhi kebutuhan dana perusahaan, maka hal ini membuat perusahaan untuk menggunakan hutang agar dapat memenuhi pendanaan tersebut, karena hutang adalah alternatif pembiayaan yang murah. Dari sudut pandang investor, pertumbuhan penjualan suatu perusahaan merupakan tanda perusahaan memiliki aspek yang menguntungkan, dan investor pun akan mengaharapkan tingkat pengembalian (rate of return) dari investasi yang dilakukan menunjukkan perkembangan yang baik. Sehingga $\mathrm{H} 2$ penelitian ini diterima yang menyatakan bahwa sales growth secara parsial berpengaruh terhadap kebijakan hutang.

3. Pengaruh Kebijakan Dividen terhadap Kebijakan Hutang

Variabel kebijakan dividen terhadap kebijakan hutang secara parsial menunjukkan tingkat nilai signifikan sebesar 0,000 dimana nilai $0,000<0.05$. Sehingga penelitian ini berhasil membuktikan bahwa kebijakan dividen mempunyai pengaruh yang signifikan terhadap kebijakan hutang. Hasil ini sesuai dengan hipotesis yang diajukan yaitu kebijakan dividen berpengaruh positif dan signifikan terhadap kebijakan hutang. Hasil penelitian yang dilakukan konsisten dengan penelitian yang dilakukan oleh (Hikmawati et al., 
2017), (Sheisarvian, 2015) yang menyatakan bahwa kebijakan dividen berpengaruh terhadap kebijakan hutang. Namun terdapat pula hasil penelitian yang tidak sejalan dengan penelitian yang dilakukan, seperti penelitian yang dilakukan oleh Akbar dan Ruzikna (2017), Rohmah, dkk (2018), Putri (2016), Bahri (2017), Khusniyah, dkk (2018) yang menyatakan bahwa kebijakan dividen tidak memiliki pengaruh terhadap kebijakan hutang. Kebijakan dividen merupakan bagian yang tidak dapat dipisahkan dengan keputusan pendanaan perusahaan, karena hal ini merupakan suatu tindakan yang dilakukan oleh manajemen perusahaan untuk mendanai operasional perusahaan dengan menggunakan modal yang pendanaannya berasal dari hutang perusahaan. Kebijakan dividen menyangkut masalah penggunaan laba yang menjadi hak para pemegang saham, pada dasarnya laba tersebut dapat dibagi sebagai dividen atau ditahan untuk diinvestasikan kembali. Sehingga H3 pada penelitian ini diterima yang menyatakan bahwa kebijakan dividen secara parsial berpengaruh signifikan terhadap kebijakan hutang.

4. Pengaruh Free Cash Flow, Sales Growth dan Kebijakan Dividen terhadap Kebijakan Hutang

Variabel free cash flow, sales growth, dan kebijakan dividen terhadap kebijakan hutang secara simultan menunjukkan bahwa nilai F-hitung sebesar 12,069 dan Ftabel sebesar 3.09 dengan nilai signifikansi sebesar 0,000. Maka Fhitung > Ftabel $(12,069>3.09)$ dengan tingkat signifikansi $0,000<0,05$. Sehingga penelitian ini diterima, artinya variabel free cash flow, sales growth dan kebijakan dividen secara simultan berpengaruh signifikan terhadap kebijakan hutang.

\section{Penutup}

Penelitian ini bertujuan untuk melihat pengaruh free cash flow, sales growth, dan kebijakan dividen terhadap kebijakan hutang pada perusahaan sektor property, real estate dan kontruksi bangunan yang terdaftar di Bursa Efek Indonesia (BEI) dengan periode pengamatan tahun 2014-2018. Dari hasil analisis data pada bab sebelumnya, maka dapat diambil kesimpulan sebagai berikut:

1. Berdasarkan hasil pengujian secara parsial melalui uji t didapatkan hipotesis pertama (H1) diketahui bahwa variabel free cash flow memiliki pengaruh yang signifikan terhadap kebijakan hutang. Dengan nilai thitung sebesar 3,212 dan nilai signifikan sebesar 0,002 dengan arah yang positif. Hasil ini menjelaskan apabila perusahaan yang memiliki free cash flow yang tinggi, maka akan cenderung menggunakan hutang untuk kegiatan pendanaan.

2. Berdasarkan hasil pengujian secara parsial melalui uji t didapatkan hipotesis kedua (H2) diketahui bahwa variabel sales growth memiliki pengaruh signifikan terhadap kebijakan hutang. Dengan nilai thitung sebesar -2,631 dan nilai signifikan sebesar 0,010 dengan arah yang negatif. Hasil ini menjelaskan apabila sales growth perusahaan tinggi maka menunjukkan kemampuan perusahaan menghasilkan laba yang stabil. Sales growth pada tahun sebelumnya secara berkala dapat digunakan untuk memprediksi sales growth pada tahun yang akan datang.

3. Berdasarkan hasil pengujian secara parsial melalui uji t didapatkan hipotesis ketiga (H3) diketahui bahwa variabel kebijakan dividen memiliki pengaruh signifikan terhadap kebijakan hutang. Dengan nilai thitung sebesar 4,113 dan nilai signifikan sebesar 0,000 dengan arah yang positif. Hasil ini menjelaskan apabila perusahaan melakukan pembayaran dividen tunai kepada para pemegang saham maka akan meningkatkan penggunaan hutang perusahaan.

4. Berdasarkan hasil pengujian secara simultan melalui uji $\mathrm{F}$ untuk variabel free cash flow, sales growth dan kebijakan dividen memiliki pengaruh signifikan terhadap kebijakan hutang. Menunjukkan bahwa nilai F-hitung sebesar 12,069 dan nilai signifikansi sebesar 0,000. Sehingga menunjukkan bahwa H4 secara simultan dalam penelitian ini memiliki pengaruh positif terhadap kebijakan hutang.

Dalam penelitian ini, peneliti mengalami keterbatasan yang menghambat hasil penelitian agar sesuai dengan hipotesis yang diajukan, masih adanya sejumlah variabel lain yang belum digunakan dan memiliki kontribusi besar dalam mempengaruhi kebijakan hutang yang terjadi dalam sebuah perusahaan. Dapat dilihat dari hasil pembahasan penelitian ini dapat disampaikan bahwa nilai $\mathbf{R}^{2}$ sebesar 0,251 yang berarti 
$25,1 \%$ variasi dari semua variabel bebas dapat menjelaskan variabel terikat dan sisanya $74,9 \%$ diterangkan oleh variabel lain yang tidak diajukan dalam penelitian ini.

Untuk penelitian selanjutnya diharapkan untuk menambah variabel-variabel serta proksi lain dalam model penelitian sehingga mampu memberikan gambaran variasi lain lagi dalam kebijakan hutang.

Bagi pihak perusahaan, diharapkan hasil penelitian yang dilakukan dapat digunakan sebagai masukan dan acuan dalam menetapkan tindakan pengaruh free cash flow, sales growth dan kebijakan dividen terhadap menetapkan kebijakan hutang.

Hasil penelitian ini diharapkan dapat memberikan masukan kepada investor dengan melihat kondisi perusahaan melalui tingkat hutang yang dimiliki yang didukung dengan nilai free cash flow, sales growth serta kebijakan dividen sebelum melakukan investasi saham.

\section{Daftar Pustaka}

Ahmad, 1., \& munawir. (2018). Sistem informasi manajemen: buku referensi. In lembaga komunitas informasi teknologi acceh (kita).

Akbar, d., \& ruzikna. (2016). Pengaruh struktur kepemilikan, free cash flow, struktur aset, dan kebijakan dividen terhadap kebijakan hutang. Jom fisip.

Bahri, s. (2017). Pengaruh kepemilikan manajerial, kebijakan dividen, profitabilitas, ukuran perusahaan dan arus kas bebas (free cash flow) terhadap kebijakan hutang. Jurnal penelitian teori dan terapan akuntansi.

Brigham, f, e., \& houston. (2011). Dasar-dasar manajemen keuangan terjemahan. Edisi 10. Jakarta: selemba empat.

Deviani, m. Y., \& sudjarni, 1. K. (2018). Pengaruh tingkat pertumbuhan, struktur aktiva, profitabilitas, dan likuiditas terhadap struktur modal perusahaan pertambangan di bei. E-jurnal manajemen universitas udayana. Https://doi.org/10.24843/ejmunud.2018.v7.i03.p04

Dewi, a. S., sari, d., \& abaharis, h. (2018). Pengaruh karakteristik dewan komisaris terhadap kinerja perusahaan manufaktur di bursa efek indonesia. Jurnal benefita. Https://doi.org/10.22216/jbe.v3i3.3530

Dewi nur khusniyah, maslichah, j. (2018). Pengaruh kepemilikan manajerial, institusional, dan profitabilitas terhadap kebijakan hutang. Jurnal riset akuntansi dan keuangan fakultas bisnis $u k d w$.

Harjito, d. A. (2011). Teori pecking order dan trade-off dalam analisis struktur modal di bursa efek indonesia. Jurnal siasat bisnis. Https://doi.org/10.20885/jsb.vol15.iss2.art3

Hikmawati, m. N., ulfah, y., \& fakhroni, z. (2017). Pengaruh pertumbuhan penjualan, dividen, dan investasi terhadap hutang pada perusahaan manufaktur terdaftar di bursa efek indonesia. Http://journal.feb.unmul.ac.id/index.php/inovasi inovasi.

Husnan, s., \& pudjiastuti, e. (1994). Dasar-dasar manajemen keuangan. Yogyakarta: upp amp ykpn. Ekonomi.

Jensen, m. C. (1986). Journal of social and personal. Journal of social and personal relationship.

Jensen, m. C., \& meckling, w. H. (1976). Theory of the firm: managerial behavior, agency costs and ownership structure. Journal of financial economics. Https://doi.org/10.1016/0304-405x(76)90026-x

Lehn, k., \& poulsen, a. (1989). Free cash flow and stockholder gains in going private transactions. The journal of finance. Https://doi.org/10.1111/j.1540-6261.1989.tb04390.x

Mardiyati, u., \& dkk. (2014). Pengaruh kepemilikan institusional, ukuran perusahaan, profitabilitas dan risiko bisnis terhadap kebijakan hutang pada perusahaan manufaktur yang terdaftar di bursa efek indonesia periode 2008-2012. Jurnal riset manajemen sains indonesia.

Martha, 1., sogiroh, n. U., magdalena, m., susanti, f., \& syafitri, y. (2018). Profitabilitas dan kebijakan dividen terhadap nilai perusahaan. Jurnal benefita. Https://doi.org/10.22216/jbe.v3i2.3493

Masdupi, e. (2005). Analisis dampak struktur kepemilikan pada kebijakan hutang dalam mengontrol konflik keagenan. Jurnal ekonomi dan bisnis indonesia.

Mega mulianti, f. (2010). Analisis faktor-faktor yang mempengaruhi kebijakan hutang dan pengaruhnya 
terhadap nilai perusahaan. Universitas diponegoro.

Myers, s. C. (1984). The capital structure puzzle. The journal of finance. Https://doi.org/10.2307/2327916

Neswari, p. Paramitha a., \& priyadi, m. Patuh. (2017). Faktor-faktor yang mempengaruhi kebijakan deviden perusahaan manufaktur di bei. Jurnal ilmu dan riset akuntansi.

Nofiani, r., \& gunawan, b. (2018). Pengaruh kepemilikan institusional, free cash flow (fcf), dan investment opportunity set (ios) terhadap kebijakan hutang (studi empiris pada perusahaan manufatur yang terdaftar di bei tahun 2014-2016). Reviu akuntansi dan bisnis indonesia. Https://doi.org/10.18196/rab.020228

Oktariyani, o., \& hasanah, a. (2019). Pengaruh free cash flow, likuiditas dan kepemilikan asing terhadap kebijakan hutang. Journal of applied managerial accounting.

Palestin, h. S. (2008). Analisis pengaruh struktur kepemilikan, praktik corporate governance dan kompensasi bonus terhadap manajemen laba. Analisis pengaruh struktur kepemilikan, praktik corporate governance dan kompensasi bonus terhadap manajemen laba.

Posner, r. A., \& jensen, m. C. (2009). Agency costs of free cash flow, corporate finance, and takeovers. In corporate bankruptcy. Https://doi.org/10.1017/cbo9780511609435.005

Safitri, s., \& akhmadi, a. (2017). Pengaruh profitabilitas dan pertumbuhan perusahaan terhadap struktur modal dengan ukuran perusahaan sebagai variabel moderating. Sains: jurnal manajemen dan bisnis. Https://doi.org/10.35448/jmb.v9i2.4225

Sheisarvian, r. (2015). Pengaruh kepemilikan manajerial, kebijakan dividen dan profitabilitas terhadap kebijakan hutang (studi pada perusahaan manufaktur yang tercatat di bei periode 2010-2012). Jurnal administrasi bisnis s1 universitas brawijaya.

Simanungkalit, e. R. (2017). Pengaruh tata kelola perusahaan dan struktur kepemilikan terhadap efisiensi investasi perusahaan. Jurnal akuntansi bisnis, universitas katolik soegijapranata.

Sudirman. (2015). Pasar modal dan manajemen portofolio. In sultan amai press.

Sugiyono. (2015). Metode penelitian. Metode penelitian.

Sugiyono. (2018). Metode penelitian kuantitatif,kualitatif dan r\&d. In ke-26.

Suweta, n., \& dewi, m. (2016). Pengaruh pertumbuhan penjualan, struktur aktiva, dan pertumbuhan aktiva terhadap struktur modal. None.

Umi mardiyati, gatot nazir ahmad, r. P. (2012). Pengaruh kebijakan dividen, kebijakan hutang dan profitabilitas terhadap nilai perusahaan manufaktur yang terdaftar di bursa efek indonesia (bei) periode 2005-2010. Jurnal riset manajemen sains indonesia (jrmsi).

Zuhria, s. F., \& riharjo, i. B. (2016). Pengaruh profitabilitas, free cash flow , pertumbuhan penjualan, ukuran perusahaan terhadap kebijakan hutang. Jurnal ilmu dan riset akuntansi. 